\title{
Physician Decision
}

National Cancer Institute

\section{Source}

National Cancer Institute. Physician Decision. NCI Thesaurus. Code C48250.

A position, opinion or judg ment reached after consideration by a physician with reference to subject. 